\title{
Sinergity between the Village Government and PT. Suprabari Mapanindo Mineral (SMM) in Application of Corporate Social Responsibility (CSR)
}

Yoyok Dwi Wicaksono*, Setia Budhi, Budi Suryadi

Master Program of Government Science, Lambung Mangkurat University, Banjarmasin, Indonesia

\author{
DOI: $10.36348 /$ sijlcj.2020.v03i06.003 $\quad$ | Received: 29.05.2020 | Accepted: 05.06.2020 | Published: 12.06 .2020 \\ *Corresponding author: Yoyok Dwi Wicaksono
}

\section{Abstract}

Synergy is a combination of various parties that can work together. This is intended to benefit through good coordination and communication. Thus we get the same view and mutual respect between the two parties. This study aims to describe how the synergy between the village government and the company, PT. Suprabari Mapanindo Mineral (SMM) especially in implementing Corporate Social Responsibility (CSR). A qualitative approach was used in this study. A descriptive method is used to describe field findings. Data collection techniques through three stages; observation, documentation, and interview. Analysis of Miles and Huberman's model data gave rise to research saturated data through; data reduction, data presentation, and drawing data conclusions. Based on the results of the study explained that the implementation of CSR of PT. Suprabari Mapanindo Mineral (SMM) and Lemo I Village Government have a synergized program. The program implemented is carried out collaboratively between the two. The form of activities carried out specifically in economic programs, infrastructure development, education, social welfare, health, sports, and youth.

Keywords: synergy, communication, and collaboration.

Copyright @ 2020: This is an open-access article distributed under the terms of the Creative Commons Attribution license which permits unrestricted use, distribution, and reproduction in any medium for non-commercial use (NonCommercial, or CC-BY-NC) provided the original author and source are credited.

\section{Preliminary}

North Barito Regency is an area that has a wealth of natural resources ranging from oil, gas, coal and other $\mathrm{C}$ minerals. Especially in Lemo Village which is located in Teweh Tengah District has sufficient natural resource potential to be a source of PAD North Barito Regency, namely coal mining which happens to be managed by PT. Suprabari Mapanindo Mineral (SMM). An interesting thing to study in this research is the involvement of CSR (Corporate Social Responsibility) in PT. Suprabari Mapanindo Mineral (SMM) to Lemo village government related to the empowerment of the community, development assistance in Lemo village, and other social activities related to government activities in Lemo village itself [1].

Mining activities themselves initially brought two sides of benefits provided to the Lemo Village government and the Lemo Village community. The benefit of the Lemo village government is that it is expected to be able to provide social assistance to create harmony and synergy in community activities. Benefits for the community around the village of Lemo which happens to be a coal mine managed by PT. Suprabari Mapanindo Mineral (SMM) is to open jobs for the surrounding community, the existence of cooperation in the field of food catering services, and increase the speed of economic rotation in the Village Lemo.

The existence of a mining company in Lemo village has triggered social changes in the lives of local people. In the past, the custom of the Lemo Village community around the mine who always depended on natural resources by working as a farmer or farming changed as social changes occurred in the central area of the mine's operations. The change that might be made striking and can be seen immediately is a shift in people's living habits to modernization by the existence of a mining company PT. Suprabari Mapanindo Mineral (SMM). As a result, they are marginalized because they are unable to compete with migrants to find work.

Social inequality began to emerge from here, this is what makes people work and have an instant thought to meet all their needs of life [2]. One of the most often done is working as illegal loggers (illegal logging perpetrators) or in the term in the village of Lemo is a woodworker who often clashes with applicable legal provisions. This is what the local government rarely thinks about in granting mining permits. In a condition, all the problems that arise are 
turned into issues that trigger vertical and horizontal conflicts from various parties with an interest in the smooth operation of the mine in Lemo Village.

Efforts made to bridge various interests in the management of natural resources, the issue of social responsibility of a CSR (Corporate Social Responsibility) was created, namely the implementation of development programs, empowerment to the community as well as infrastructure development assistance and the provision of other social assistance to the government of Lemo Village [3, 4]. Corporate Social Responsibility (CSR) activities are social programs that exist in the AD ART (Statutes of the Household) a company related to providing proof of social services to the communities around the mine as a result of being affected by their land used as a mining area.

One example of the implementation of PT. Suprabari Mapanindo Mineral (SMM) social responsibility through Corporate Social Responsibility (CSR) is the implementation of the development and community empowerment program of Lemo Village and company participation in providing social assistance to the Lemo Village Government in the form of procurement of supporting facilities and infrastructure to support activities village government and capital assistance for infrastructure development in the form of cementing roads / building bridges in Lemo Village. At this time there are only 4 legal umbrella that requires companies to carry out CSR activities to the environment and village / regional governments affected by the company's location. The legal basis / legal umbrella that already exists includes:

1. State-Owned Enterprises (SOEs) required doing Partnership and Community Development Program (PKBL) following the State Minister of SOE Regulation: Per-05 / MBU / 2007 Article 1 paragraph 6 and 7.

2. Regulations for Limited Liability Companies (PT) that manage Natural Resources (SDA) are required to implement responsible social and environmental because it has been regulated in Limited Liability Company Law No.40 of 2007.

3. For foreign investment, regulated in Law Number 25 the Year 2007 concerning Investment,

4. For oil and gas management companies, bound by Law No. 22 of 2001, concerning Oil and Gas, Article 13 paragraph 3 [5].

However, based on ISO 26000, it is an international standard in the field of Corporate Social Responsibility. Based on the understanding that Social Responsibility is very important for business sustainability. The focus of ISO is on organizational governance, human rights (HAM), employment, the environment, fair operating/fair operating practices, consumer issues, and community development. ISO itself aims to assist various forms of organization in implementing social responsibility. By providing practical guidance, and expanding public understanding of social responsibility [6]. CSR is the domain of the Central Government because both the Minister of SOE regulations, the PT Act, the PMA Law, the Oil, and Gas Law were made by the DPR together with the Central Government. Whereas the role of the Regional Government is to carry out monitoring with people of the Environmental and Social Impact Analysis and assess the extent to which the company can provide benefits to stakeholders in this case to the Lemo Village Government and the community around the mine. The regional government does not have the authority to influence CSR because it is a full right exercised by the Company related to the management of funds.

\section{RESEARCH METHODS}

In this research study so that we can see, know and describe the actual situation in detail and actual by looking at the problems and objectives of the research that have been presented previously, the research methods that can be used in this research lead to the use of qualitative research methods [7]. Qualitative methods as a research procedure that produces descriptive data in the form of written or spoken words from people and observable behavior. According to them, this approach is directed at the background and the individual holistically (whole). The research used to examine the condition of natural objects, where researchers are key instruments [8].

Research conducted by researchers is located in North Barito Regency, Central Kalimantan Province, precisely in Central Teweh District, Lemo Village. Administratively, Teweh Tengah District consists of 8 villages and consisting of Lemo I Village, Lemo II Village, Pendreh Village, Rimba Sari Village, Sei Rahayu Village, Sei Rahayu II Village, Beringin Raya Village, and Datai Nirui Village. In Teweh Baru Subdistrict there are 2 administrative regions in the form namely Kelurahan Melayu and Kelurahan Lanjas. Researchers focus on researching, Village Government Synergy, and PT. Suprabari Mapanindo Mineral in the implementation of Corporate Social Responsibility (CSR), and the form of programs carried out by the Village Government and PT. Suprabari Mapanindo Mineral in implementing Corporate Social Responsibility (CSR). And limiting this problem is only the extent of the synergy between the Lemo Village Government and PT. Suprabari Mapanindo Mineral in implementing Corporate Social Responsibility.

Determination of the main resource is called the first participant selection (the primary selection), which is direct selection provides an opportunity for researchers to determine the sample of the informants encountered. Meanwhile, if the researcher cannot determine the participant directly, the researcher can alternatively choose the second informant (secondary selection). In this study, the key informants were the 
head of the Lemo village, the secretary of the Lemo village, the head of government, the head of development, the general head, the head of finance, the public relations officer of PT. SMM, CD / CSR Dept. Head of PT. SMM, program target community in the village;

Table-1: Research Informants

\begin{tabular}{|l|l|l|l|}
\hline No & Name of the Informant & Agency Name & Position \\
\hline 1 & Nurifansyah & Lemo Village & Village head \\
\hline 2 & Zainal Arifin & Lemo Village & Village secretary \\
\hline 3 & Malik Abdul Azis & Lemo Village & Head of Government \\
\hline 4 & Fitri Handayani & Lemo Village & $\begin{array}{l}\text { Kaur } \\
\text { Development }\end{array}$ \\
\hline 5 & Rusdianoor & Lemo Village & General Affairs \\
\hline 6 & Weni Sri Rezeki & Lemo Village & Head of Finance \\
\hline 7 & Ibn Solihin & PT. SMM & $\begin{array}{l}\text { CD / CSR Dept. } \\
\text { Head of PT. SMM }\end{array}$ \\
\hline 8 & Fakhrur Razy & PT. SMM & $\begin{array}{l}\text { Public Relations of PT. SMM } \\
\text { Target citizens } \\
\text { program }\end{array}$ \\
\hline 9 & 1. Maman & $\begin{array}{l}\text { Community members } \\
\text { Lemo Village }\end{array}$ & \begin{tabular}{l} 
Juwandy \\
\hline
\end{tabular}
\end{tabular}

Data collection techniques are a method used by researchers to obtain the data needed in their research. In qualitative research data is usually collected with several data collection techniques, namely: 1) Interviews, 2) Observation, and 3) Documentation. Data analysis activities began from the researchers conducted pre-field activities until the completion of the study, data analysis was carried out continuously without stopping until the data is saturated. Qualitative data analysis is carried out interactively and continues continuously until it is complete so that the data is already saturated. The size of data saturation is characterized by no longer obtaining new data or information. Activities in the analysis include data collection, reduction, data presentation, and concluding $[9,10]$.

\section{RESULTS AND DISCUSSION}

Synergy as a combination or combination of elements or parts that can produce better and greater output than is done individually $[11,12]$. Besides, a combination of several elements produces a superior product. Synergy easily occurs when the components are: 1 . able to think of synergies, 2 . there is a common view and 3. Respect each other. Based on the Lemo I Village Revenue and Expenditure Budget (APBDes) and the CSR (Corporate Social Responsibility) Basis of the PT. Suprabari Mapanindo Mineral (SMM) can be said to be synergy / there is a common view, goals, and mutual respect in terms of programming for the sake of their respective responsibilities to the people of Lemo I Village.

Synergy arises from the need to build a society based on mutually beneficial cooperation based on rational, open, and democratic thoughts through 2 (two) main stages, namely good and effective coordination and communication so that synergy is achieved [13,6]. Synergy is a process that must be passed by each party where time and consistency is needed, supported by mutual trust and creative cooperation [14]. The synergy that occurred between Lemo I Village Government and PT. Suprabari Mapanindo Mineral is solely carried out to achieve the objectives of each organization. If the Lemo I Village Government has to serve, protect, and develop and develop the village community. So is the case with PT.

The government is derived from the intended command word, as follows: 1). Orders are words that mean to do something. 2). Government is the power of the government of a State (Region, State) or the highest governing body of a State (such as a cabinet is a government) [15]. So based on the above understanding in this study, the village government implemented the village administration together with the BPD to run a good governance system following Law No. 6 of 2014 concerning Villages to achieve the objectives of the village itself. The government in the broad sense, with the government in the broad sense, of course, has the meaning of the Government in the narrow sense, namely: 1). The government in the strict sense, namely: the act of ruling carried out by the Executive, namely the President is assisted by his Ministers to achieve the goals of the country. 2) The government in a broad sense, namely: Acts governed by the Legislature, Executive, and judiciary to achieve the objectives of State Government [16, 17].

Activities/programs carried out by the Lemo I Village Government and PT. Suprabari Mapanindo Mineral is considered to have synergy, this was concluded by researchers through interviews conducted with several speakers and the results of field observations supported by data that there are a lot of activities/programs from the Lemo I Village Government and PT. Suprabari Mapanindo Mineral (SMM) has many programs in common. Lemo I Village Government Program and PT. Suprabari Mapanindo Mineral (SMM) is said to be synergy, this is following 
Covey's opinion that synergy is the integration of results between several superior products from the Lemo I Village Government and PT. Suprabari Mapanindo Mineral (SMM) for the sake of creating good and consistent output and mutual respect between the two organizations.

Realizing synergy is a joint success between the Lemo I Village Government and PT. Suprabari Mapanindo Minerals that are built from habits. In realizing this synergy does not mean a compromise in the middle, but looking for alternatives or solutions in achieving common goals. The program has been implemented by the Lemo I Village Government and PT. Suprabari Mapanindo Mineral is considered to be a synergy, a program that can be said to be a synergy if both parties have creative cooperation and mutual trust and respect in the implementation of the program.

\section{Lemo I Village Government Program according to the 2018 APBDes}

a. Development Sector: in the realization of the 2018 budget, the Government of Lemo I Village has completed the construction of the connecting village road in Teluk View and Durian Ramba sub-villages with a total length of cementing the $450 \mathrm{~m}$ road with a width of $4 \mathrm{~m}$. The construction of a clean water network supported by PT. Suprabari Mapanindo Mineral for the community around the mine.

b. Economic Sector: In the realization of the 2018 budget, the Government of Lemo I Village has implemented a training program on rattan crafts and marketing of rattan by bringing in Mentors from Palangkaraya This aims to make Lemo I Village community capable of works capable of generating economic income.

c. Field of Education: in the realization of the 2018 budget the Lemo I Village Government assisted in the procurement of learning tools, as well as tools /means play for early childhood education (PAUD).

d. Social Welfare Sector: Realization of the 2018 budget The Lemo I Village Government has organized an employment training program so that the people of Lemo I Village have skills that you can apply for a job at PT. Suprabari Mapanindo Mineral. This training includes training drive and cooking training.

e. Public Health Sector: Realization of the 2018 budget The Lemo I Village Government has carried out the activities of fostering and organizing free medical treatment through posyandu, free health checks for Lemo I villagers in collaboration with PT. Suprabari Mapanindo Mineral.

f. Field of Sports and Youth: Realization of the 2018 budget Lemo I Village Government has carried out debriefing and coaching activities to athlete Porprov and give pocket money to athlete from the village of Lemo I. In terms of facilities and infrastructure Sports Lemo I Village Government has also completed construction of facilities Sports Badminton and Futsal building managed by the youth of Lemo I Village and included in the original income of Lemo I Village.

The PT. Suprabari Mapanindo Mineral program is based AD ART On the Implementation of CSR in 2016

a. Economy and Infrastructure Development: Realization AD ARTCSR (Corporate Social Responsibility) PT. Suprabari Mapanindo Mineral in 2018 has conducted a program/training activity of rattan crafts by helping to bring in mentors from Palangka Raya. In the field of infrastructure development, PT. Suprabari Mapanindo Mineral (SMM) has helped open access roads from the Teluksee hamlet to the Durian Ramba hamlet, Tangocin hamlet, and the Bamban river hamlet. As well as assisting the Lemo I Village Government in the provision of clean water networks for the communities around the mine.

b. Field of Education: Realization AD ARTCSR (Corporate Social Responsibility) PT. Suprabari Mapanindo Mineral has conducted honorary teacher fulfillment activities for junior high schools, elementary schools, kindergartens, and PAUD. As well as providing scholarships to tertiary institutions for high achieving and underprivileged children in Lemo I Village. PT. Suprabari Mapanindo Mineral provides operational assistance in the form of whiteboards, desks, and chairs for students in several schools.

c. Health sector: Realization AD ARTCSR (Corporate Social Responsibility) PT. Suprabari Mapanindo Mineral in 2018 cooperated with Lemo I Village Government and Lemo Health Center in providing health education, free medical treatment, and free health check services.

d. Sports sector: Budget realization $\mathrm{AD}$ ARTCSR (Corporate Social responsibility) PT. Suprabari Mapanindo Mineral in 2018 provided financial assistance and pocket money for athletes competing in Porprov in October 2018 in Muara Teweh City. On which sideotherPT. Suprabari Mapanindo Mineral also held a competition eventvolleyballand futsal for the people of Lemo I Village in collaboration with the Lemo I Village Government. PT. Suprabari Mapanindo Mineral helped in giving gifts and coaching money to the team that won the SMM cup competition. 
e. The field of social welfare: Realization AD ARTCSR (Corporate Social Responsibility) PT. Suprabari Mapanindo Mineral in 2018 the company collaborated with the Lemo I Village Government to bring mentors in providing pre-employment training for people who want to get a job at the company PT. Suprabari Mapanindo Mineral.

\section{CONCLUSION}

Lemo I Village Government and PT. Suprabari Mapanindo Mineral (SMM) in implementing CSR (Corporate Social Responsibility) can be said to be a synergy because the programs carried out by both parties in implementing CSR respect each other / do not interfere in each other's household affairs and there is a common view regarding programs. Which is implemented on the application of CSR. The forms of programs that can be said to be synergy between Lemo I Village Government and PT. Suprabari Mapanindo Mineral (SMM) on the implementation of CSR includes programs in the fields of economy and infrastructure development, education, social welfare, health and sports, and youth. Lemo I Village Government to increase creative cooperation and continue to coordinate well so that the program with PT. Suprabari Mapanindo Minerals in other fields can be realized in the CSR of PT. Suprabari Mapanindo Mineral. However, PT. Suprabari Mapanindo Mineral to be more able to develop programs in other fields that are more creative and innovative to realize community development as the original goal of Corporate Development.

\section{REFERENCES}

1. Widjaja, H. (2003). Otonomi Desa. Jakarta: PT Raja Grafindo Persada.

2. Bintarto. (1989). Interaksi Desa Kota dan Permasalahannya. Jakarta: Ghalia Indonesia.

3. Crowther, D. (2008). Corporate Social Responsibility. Gulen Aras \& Ventus Publishing Aps.
4. Fajri, M. (2003). Corporate Social Responsibility. Jakarta: Sinar Harapan.

5. Johnson, R. A., \& Greening, D. W. (2006). The Effects of Corporate Governance and Institutional Ownership Types on Corporate Social Performance. The Academy of Management Journal, 42(5), 564-576.

6. Syafiie, I. K. (2006). Ilmu Administrasi Publik. PT. Rineka Cipta: Jakarta.

7. Iskandar. (2008). Metodologi Penelitian Pendidikan dan Sosial (Kuantitatif dan. Kualitatif). Jakarta: GP Press.

8. Moleong, L. J. (2002). Metode Penelitian Kualitatif. Bandung: PT Remaja Rosdakarya.

9. Saebani, A. D. (2009). Metodologi Penelitian Kualitatif. Pustaka Setia: Bandung.

10. Sugiyono. (2016). Memahami Penelitian Kualitatif. Bandung: Alfabeta.

11. Covey, S. (2001). The 7 Habits Highly Effective Teens (Alih Bahasa; Saputra, Arvin). Jakarta: Binarupa Aksara.

12. Nurcholis, H. (2011). Pertumbuhan dan Penyelenggaraan Pemerintahan Desa. Jakarta: Penerbit Erlangga.

13. Mulyana, D. (2008). Ilmu Komunikasi: Suatu Pengantar. Bandung: Remaja Rosdakarya.

14. Ndraha, T. (1990). Pembangunan Masyarakat Mempersiapkan Masyarakat Tinggal Landas. Jakarta: PT. Rineka Cipta.

15. Keban, Y. T. (1995). Indikator Kinerja Pemerintah Daerah: Pendekatan Manajemen dan Kebijakan. Yogyakarta: Fisipol UGM.

16. Pranadjaja, M. R. (2003). Hubungan Antar Lembaga Pemerintahan. Jakarta: Sinar Grafika.

17. Suharto, E. (2008). Pekerjaan Sosial di Dunia Industri Memperkuat Tanggung Jawab Sosial Perusahaan (Corporate Social Responsibility). Bandung: Refika Aditama. 